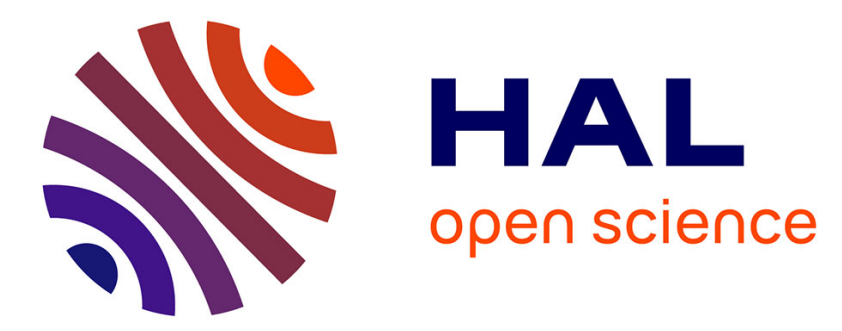

\title{
Theoretical studies of mixed-valence organometallic species for potential utilization as quantum cellular automata
}

\author{
T. Groizard, S. Kahlal, J.-F. Halet
}

\section{- To cite this version:}

T. Groizard, S. Kahlal, J.-F. Halet. Theoretical studies of mixed-valence organometallic species for potential utilization as quantum cellular automata. Journal of Organometallic Chemistry, 2017, 844, pp.35-42. 10.1016/j.jorganchem.2017.02.021 . hal-01544465

HAL Id: hal-01544465

https://hal-univ-rennes1.archives-ouvertes.fr/hal-01544465

Submitted on 5 Jul 2017

HAL is a multi-disciplinary open access archive for the deposit and dissemination of scientific research documents, whether they are published or not. The documents may come from teaching and research institutions in France or abroad, or from public or private research centers.
L'archive ouverte pluridisciplinaire HAL, est destinée au dépôt et à la diffusion de documents scientifiques de niveau recherche, publiés ou non, émanant des établissements d'enseignement et de recherche français ou étrangers, des laboratoires publics ou privés. 
Theoretical studies of mixed-valence organometallic species for potential utilization as quantum cellular automata

Thomas Groizard, Samia Kahlal, Jean-François Halet*

Institut des Sciences Chimiques de Rennes, UMR 6226 CNRS-Université de Rennes 1, Avenue du Général Leclerc, F-35042 Rennes Cédex, France

\section{Graphical Abstract}
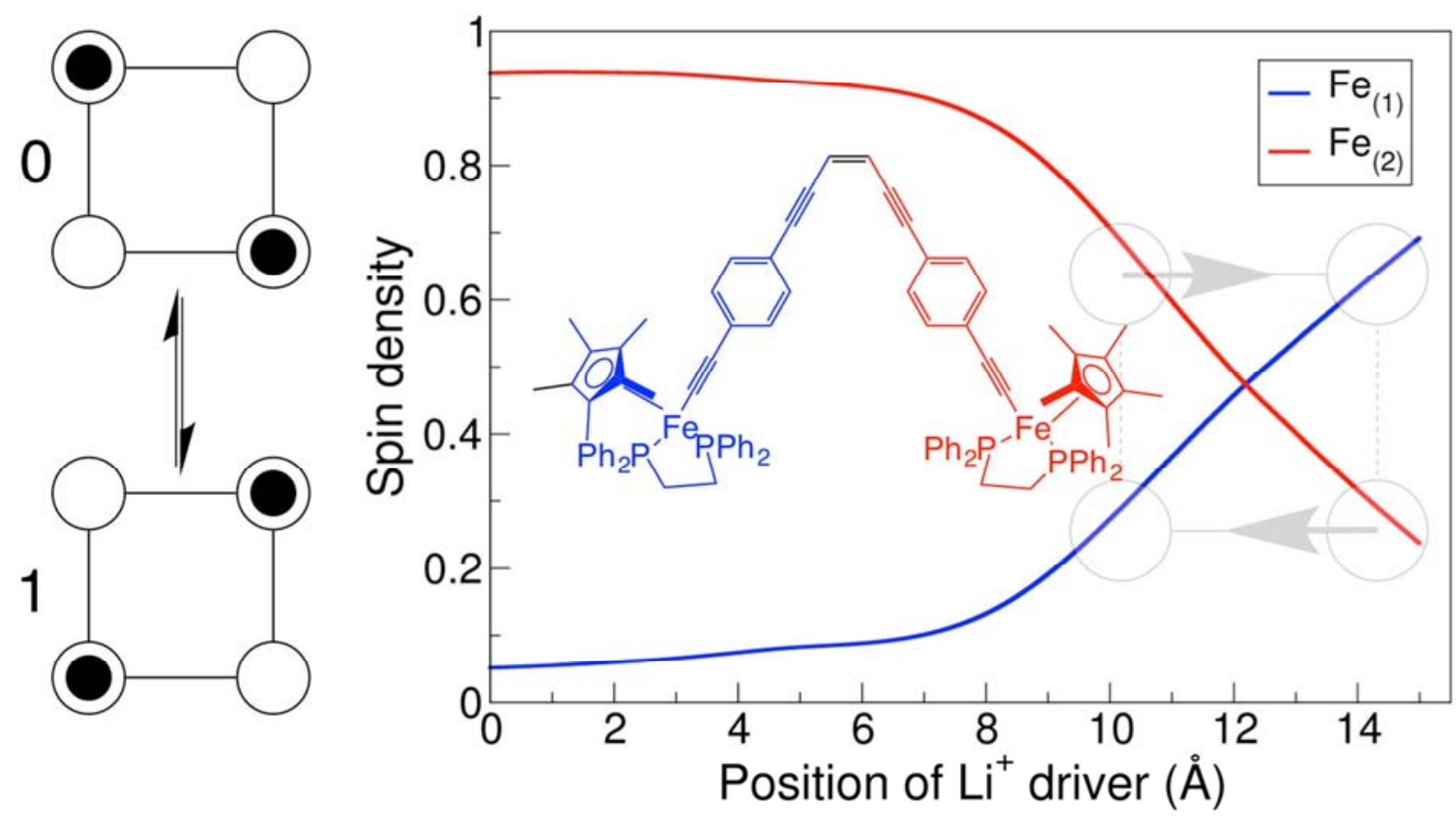


\title{
Theoretical studies of mixed-valence organometallic species for potential utilization as quantum cellular automata
}

\author{
Thomas Groizard, Samia Kahlal, Jean-François Halet* \\ Institut des Sciences Chimiques de Rennes, UMR 6226 CNRS-Université de Rennes 1, Avenue \\ du Général Leclerc, F-35042 Rennes Cédex, France
}

\begin{abstract}
The chemistry of mixed-valence complexes joins that of molecular electronics in the quantum cellular automata (QCA) paradigm, a concept which has been demonstrated to be a possible alternative to the transistor-based technology, in which binary information is encoded in the configuration of charge among redox-active molecular sites. Experimental and theoretical efforts have recently been devoted to molecular mixed-valence organometallic systems containing two and four metal centers as candidates for QCA. Properties of specific examples based on hypothetical organometallic molecules are theoretically analyzed and discussed with the aid of DFT calculations.
\end{abstract}

Keywords: Quantum-dot cellular automata . Density Functional Theory calculations . Mixedvalence . Iron . Molecular wire . Carbon chain

Dedicated to our good friend and colleague Rick Adams on the occasion of his $70^{\text {th }}$ Birthday.

\footnotetext{
* Corresponding author. E-mail address: halet@univ-rennes1.fr (J. -F. Halet)
} 


\section{Introduction}

Moore's Law stating that transistor density on electronic circuits doubles every two years [1] has driven decades of technological achievement and new materials science in the semiconductor industry [2]. However, if the pace of electronic device development is to continue in the longer term then further reductions in feature size will be required moving toward hybrid molecular electronic technology. Such a miniaturization will unfortunately be accompanied with some physical limits at the molecular scale such as poor charge conductivity, resistive heating and quantum effect (quantum tunneling). It becomes clear that it may not longer be the appropriate paradigm for realizing single-molecule devices. Taking advantage that molecules are excellent charge containers, an alternative paradigm, quantum cellular automata (QCA), was proposed by Lent et al. in 1993 and has been proven operationally at very low temperature using ca. 60-nm quantum dots [3-9]. In this novel approach to electronics, the binary language/current switch paradigm used in transistor-based devices differs by replacing on/off current states by dipole orientation within a cell. In other words, current-driven switching of transistors is replaced by electric field coupling between adjacent dipolar cells, thereby correlating dipole orientations and transmitting binary instructions.

A typical molecular QCA cell consists of four dots located at the vertices of a square containing two mobile electrons which occupy antipodal sites due to mutual Coulomb electrostatic repulsion (Figure 1a). Isolated, the two diagonal electron arrangements are energetically equivalent ground states of the cell. Juxtaposing cells can result in a QCA wire (Figure 1b) or a logic gate (Figure 1c). The electrostatic effect of neighboring cells lifts the degeneracy and results in a "1" or "0" binary state of the cell and allows transmission of 
binary information from one end to the other. Remarkably, this intercellular interaction involves no current flow between cells, steadily diminishing heat losses and being strongly faster (100-10000-fold faster) with respect to those associated with devices based on current $[10]$.

(a)

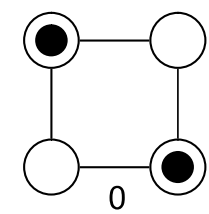

(b)

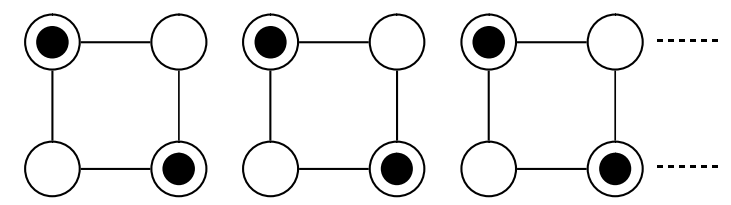

(c)
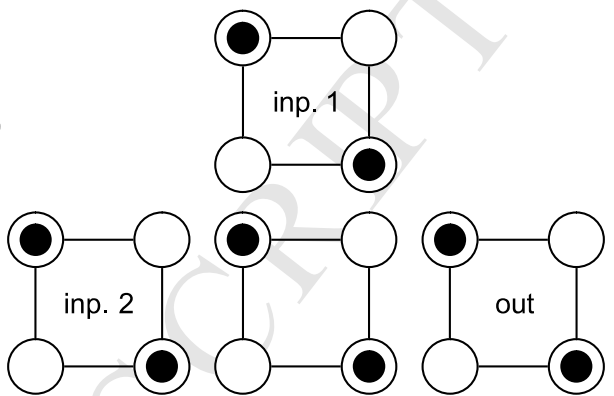

inp. 3

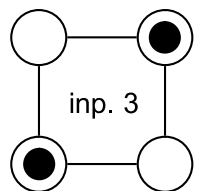

Figure 1. (a) Bistable QCA-cell states; (b) QCA wire; (c) QCA majority logic gate.

Interestingly, systems based on 1-2 nm dots, i.e., of molecular size, are expected to operate at room temperature [11], hence, the current interest in developing molecular expressions of the QCA paradigm. Covalently bound "square" molecules with four metal centers are good candidate systems for single-molecule implementation of a QCA cell in which charge is localized on specific sites and can tunnel between those sites. The role of the dots is then played by redox-active metal sites, whereas tunneling paths are provided by bridging ligands. Consequently, the metal centers must have two stable, accessible oxidation states, and sufficient interaction must exist between these redox centers. Charge localization characterizes Robin-and-Day Class-II mixed-valence (MV) species [12,13]. Thus, several MV molecules have been explored as QCA. Constructing square molecules with four electronically coupled dots containing two mobile electrons remains somewhat challenging and scarce. Indeed, efforts have been mainly focused on dipolar two-dot molecules with one 
mobile electron, i. e., half-cells, hoping that two half-cells can sufficiently interact through electrostatic forces and can arrange side by side, thus forming a "squared" structure [5].

The present work briefly reviews the different MV organometallic systems, which have been synthesized and characterized as candidate QCA and explores new model molecules using density-functional theory (DFT) calculations to provide some insight regarding i) bistable charge configuration and ii) charge switching by a neighboring molecule via Coulomb interactions.

\section{QCA candidate mixed-valence organometallic compounds}

Creutz-Taube MV bimetallic complexes and derivatives [14-16] were among the first compounds studied as half-QCA candidates. Systems representative of each Robin and Day class, such as Class-III [decaammine $(\mu$-pyrazine $)$ diruthenium $]^{5+}(\mathbf{1})$, Class-II [decaammine $(\mu-$ 4,4'-bipyridine)diruthenium $]^{5+}(2)$, and Class-I [decaammine $(\mu \text {-pipera-zine)diruthenium }]^{5+}(3)$ (Scheme 1) were theoretically studied both at the Hartree-Fock and DFT levels to evaluate the ability to switch back and forth between the two possible "0" and " 1 " states with a biasing charge (driver) [17,18]. The static charge polarization response of compounds $\mathbf{1 - 3}$ induced by a mobile $\mathrm{Li}^{+}$cation (used as the driver) was computed and examined by Braun-Sand and Wiest in two cases: one, termed "end-on", where $\mathrm{Li}^{+}$was placed along the $\mathrm{Ru}^{\cdots *} \mathrm{Ru}$ axis to simulate the neighboring cell, and another, termed "side-on", where $\mathrm{Li}^{+}$was placed also parallel but below the $\mathrm{Ru}^{\cdots}{ }^{\cdots} \mathrm{Ru}$ axis to mimic a second half QCA. As expected, theoretical results demonstrate that the more electron-delocalized complex 1 shows poor polarization whereas the more electron-localized compounds $\mathbf{2}$ and $\mathbf{3}$ exhibit the largest amount of polarization. However, because of the lack of electronic communication between the metal centers in the Class-I compound $\mathbf{3}$, the Class-II complex $\mathbf{2}$ is the best suited to be a candidate QCA. The nature of the static signal transmission through these Creutz-Taube complexes was confirmed by Tokunaga, using a variable point charge placed parallel to the $\mathrm{Ru}^{\cdots} \mathrm{Ru}$ axis 
$[19,20]$. However, the analysis of the dynamic response led him to conclude that indeed,

Class-III complexes could also be good molecular QCA candidates. A subsequent study on the analysis of Group- 8 metal dependence of the dynamic signal transmission behavior indicates that among all Class-III complexes studied, the best results are obtained with $\mathrm{Fe}$ compared to $\mathrm{Ru}$ and Os [20].
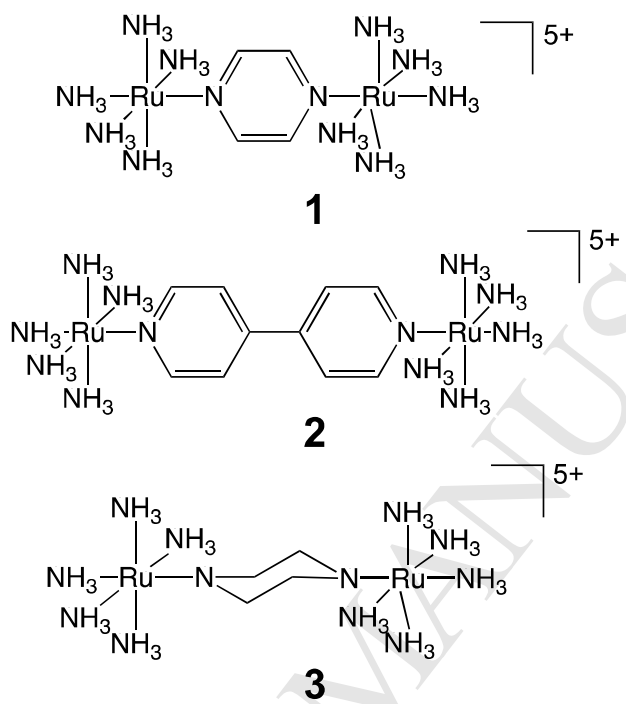

Scheme 1. Creutz-Taube complexes and derivatives studied as candidate half-QCA.

Among the several candidate QCA molecules which have been synthesized and experimentally characterized, a few contain ferrocene $\left(\mathrm{Fc}=\left(\eta^{5}-\mathrm{C}_{5} \mathrm{H}_{5}\right) \mathrm{Fe}\left(\eta^{5}-\mathrm{C}_{5} \mathrm{H}_{4}\right)\right)$ fragments in which the $\mathrm{Fe}(\mathrm{II})$ center is an ideal redox center. Fehlner and coworkers for instance have isolated the four-dot dicationic Class-II MV molecule $\left[(\mathrm{Fc})_{4}\left(\eta-\mathrm{C}_{4}\right) \mathrm{CoCp}\right]^{2+}(4$, Scheme $2, \mathrm{Cp}$ $\left.=\left(\eta^{5}-\mathrm{C}_{5} \mathrm{H}_{5}\right)\right)$ containing two ferrocene and two ferrocenium moieties arranged in a square by C-C bonds to the corners of a "cyclobutadiene" linker [21,22]. Measured electronic properties of 4, supported by a theoretical study [23], suggest that such a species is suitable for use as a component for charge-coupled QCA circuits. 


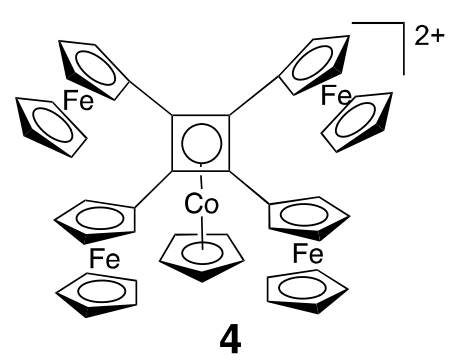

4

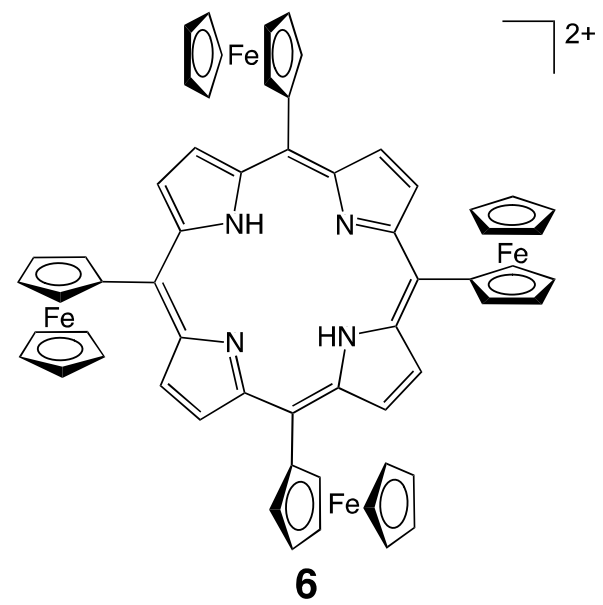

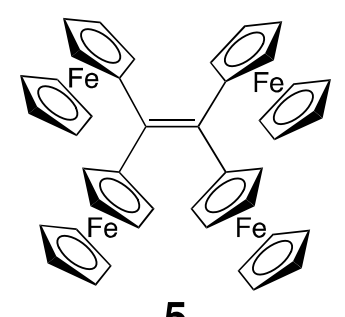

5

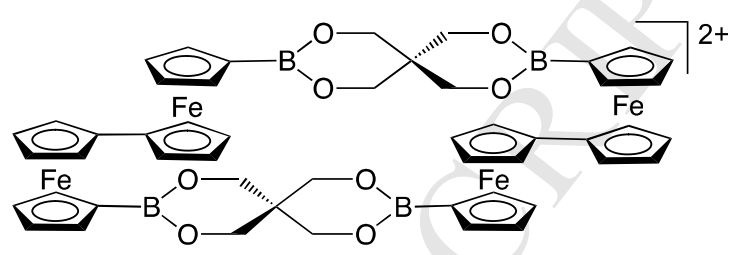

7

Scheme 2. Candidate QCA containing two ferrocene and two ferrocenium moieties: $\left[\left\{\left(\eta^{5}-\right.\right.\right.$ $\left[(\mathrm{Fc})_{4}\left(\eta^{\square}-\mathrm{C}_{4}\right) \mathrm{CoCp}\right]^{2+}(\mathbf{4}), \quad\{\mathrm{Fc}(\mathrm{C} \equiv \mathrm{C})\}_{2} \mathrm{C}=\mathrm{C}\{(\mathrm{C} \equiv \mathrm{C}) \mathrm{Fc}\}_{2}(\mathbf{5}),\left[\mathrm{H}_{2} \mathrm{TFcP}\right]^{2+}(\mathbf{6})$, and $\left.\left[\mathrm{CP}_{2} \mathrm{C}\right)\right]^{2+}$ (7).

Very recently, Low and collaborators have characterized the tetrakis(ferrocenylethynyl)ethene $\{\mathrm{Fc}(\mathrm{C} \equiv \mathrm{C})\}_{2} \mathrm{C}=\mathrm{C}\{(\mathrm{C} \equiv \mathrm{C}) \mathrm{Fc}\}_{2}$ compound (5, Scheme 2) incorporating four ferrocenyl moieties around a 1,1,2,2-tetraethynylethene entity [24]. Unfortunately, although four distinct oxidation processes are observed, spectroelectrochemical investigation reveals essentially no through bond interaction between the individual ferrocenyl fragments.

Other examples of "square" MV molecules containing two ferrocene and two ferrocenium moieties such as the 5,10,15,20-tetraferrocenylporphyrin Class-II compound $\left[\mathrm{H}_{2} \mathrm{TFcP}\right]^{2+}(\mathbf{6})$ $[25]$ and the dioxidized macrocyclic tetraferrocenyl boronate complex $\left.\left[\mathrm{CP}_{2} \mathrm{C}\right)\right]^{2+}\left(\mathrm{CP}_{2} \mathrm{C}=\right.$ $\left.\left.\mathrm{FcBO}_{2} \mathrm{C}_{5} \mathrm{H}_{8} \mathrm{O}_{2} \mathrm{BFc}\right)_{2}\right)$ [26] (7, Scheme 2) were synthesized and proposed as potentially useful for QCA. Theoretical calculations on $\left.\left[\mathrm{CP}_{2} \mathrm{C}\right)\right]^{2+}$ indicate that the two ferric centers are 
localized on the longer diagonal, in order to minimize the electrostatic repulsion over the $\mathrm{CpBO}_{2} \mathrm{C}_{5} \mathrm{H}_{8} \mathrm{O}_{2} \mathrm{BCp}$ ligands.

Other redox moieties have been used to design QCA candidates. For instance, Meyer and collaborators have shown that identical redox states at diagonally opposed vertices were also found in the rhombic $\mathrm{Fe}_{4}$ grid $\left[\mathrm{MeL}_{4} \mathrm{Fe}(\mathrm{II})_{2} \mathrm{Fe}(\mathrm{III})_{2}\right]^{6+}$ (8, Scheme 3, MeL = 4-methyl-3,5bis $\left\{6-\left(2,2^{\prime}\right.\right.$-bipyridyl $\left.)\right\}$ pyrazolyl), a configuration required for potential implementation in QCA devices [27]. Another MV molecular square $(\mathrm{Fe}(\mathrm{II}))_{2}(\mathrm{Fe}(\mathrm{III}))_{2}$ complex with two extra mobile charges occupying the opposite corners with remarkable stability for molecular expression of QCA, was also achieved by Duan et al. in the case of $\left[\mathrm{Fe}_{4}\{\right.$ bis(phenyl(2pyridyl)methanone)thiocarbohydrazonoyl $\left.\}_{4}\right]^{2+}(9$, Scheme 3) [28].
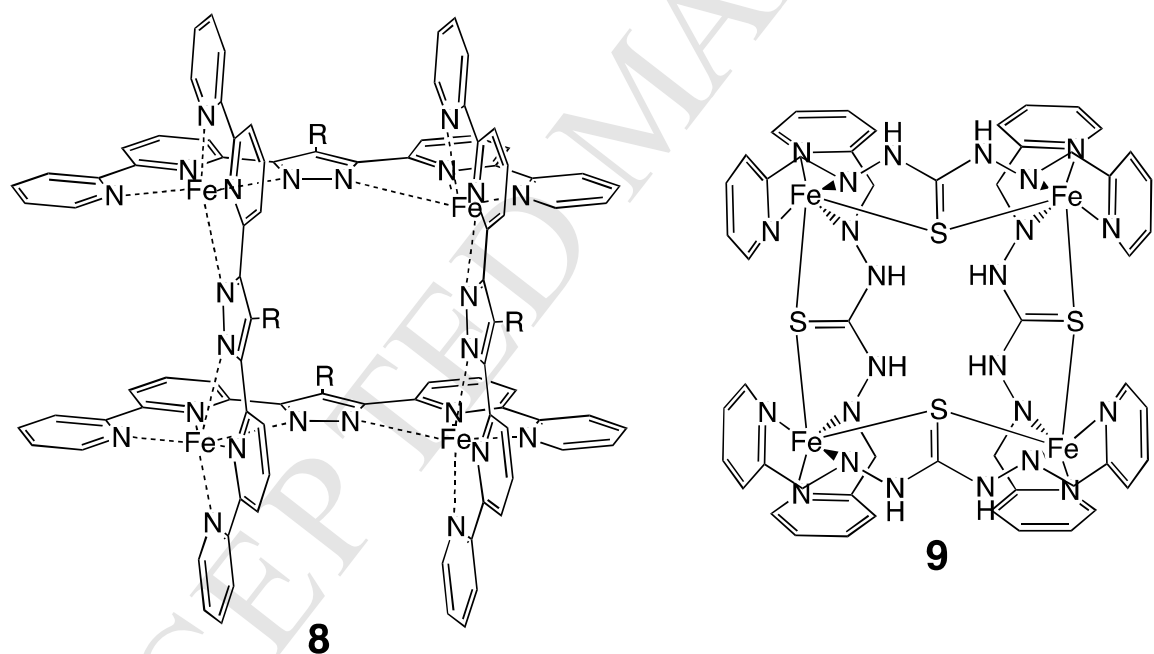
Scheme
3. $\mathrm{MV}$
$\left[\mathrm{MeL}_{4} \mathrm{Fe}_{4}\right]^{6+}$
(8)
and
$\left[\mathrm{Fe}_{4}\{\right.$ bis $(\operatorname{phenyl}(2-$

pyridyl)methanone)thiocarbohydrazonoyl $\left.\}_{4}\right]^{2+}(9)$ complexes.

Other representatives of four-metal redox systems have been reported. One of them, synthesized by Akita et al., is $\quad\left\{\mathrm{Cp}^{*}(\mathrm{dppe}) \mathrm{Fe}(\mathrm{C} \equiv \mathrm{C}) p-\mathrm{C}_{6} \mathrm{H}_{4}\right\}{ }_{2} \mathrm{C}=\mathrm{C}\{p$ $\left.\mathrm{C}_{6} \mathrm{H}_{4}(\mathrm{C} \equiv \mathrm{C}) \mathrm{Fe}(\mathrm{dppe}) \mathrm{Cp}^{*}\right\}_{2} \quad\left(\mathbf{1 0}, \quad\right.$ Scheme $\quad 4, \quad \mathrm{Cp}^{*}=\left(\eta^{5}-\mathrm{C}_{5} \mathrm{Me}_{5}, \quad\right.$ dppe $=1,2-$ bis(diphenylphosphino)ethane) where four iron centers are linked to a 
tetra(ethynylphenyl)ethene bridge [29]. However, a di-mixed-valence state has not been yet chemically characterized. More recently, the asymmetric tetraruthenium dication complex $\{$ cyclo-C([RuCp(dppe)] $)(\mathrm{CCCC}[\operatorname{RuCp}($ dppe $)]) \mathrm{C}(\mathrm{CC}[\mathrm{RuCp}($ dppe $)]) \mathrm{C}(\mathrm{CC}[\operatorname{RuCp}(\mathrm{dppe})])\}^{2+}$

(11, Scheme 4, $\left.\mathrm{Cp}=\left(\eta^{5}-\mathrm{C}_{5} \mathrm{H}_{5}\right)\right)$ has been prepared and the molecular structure determined [30]. Unfortunately, both experimental and theoretical results show a fully electron delocalized Class-III MV species, rendering it probably inappropriate for QCA application.
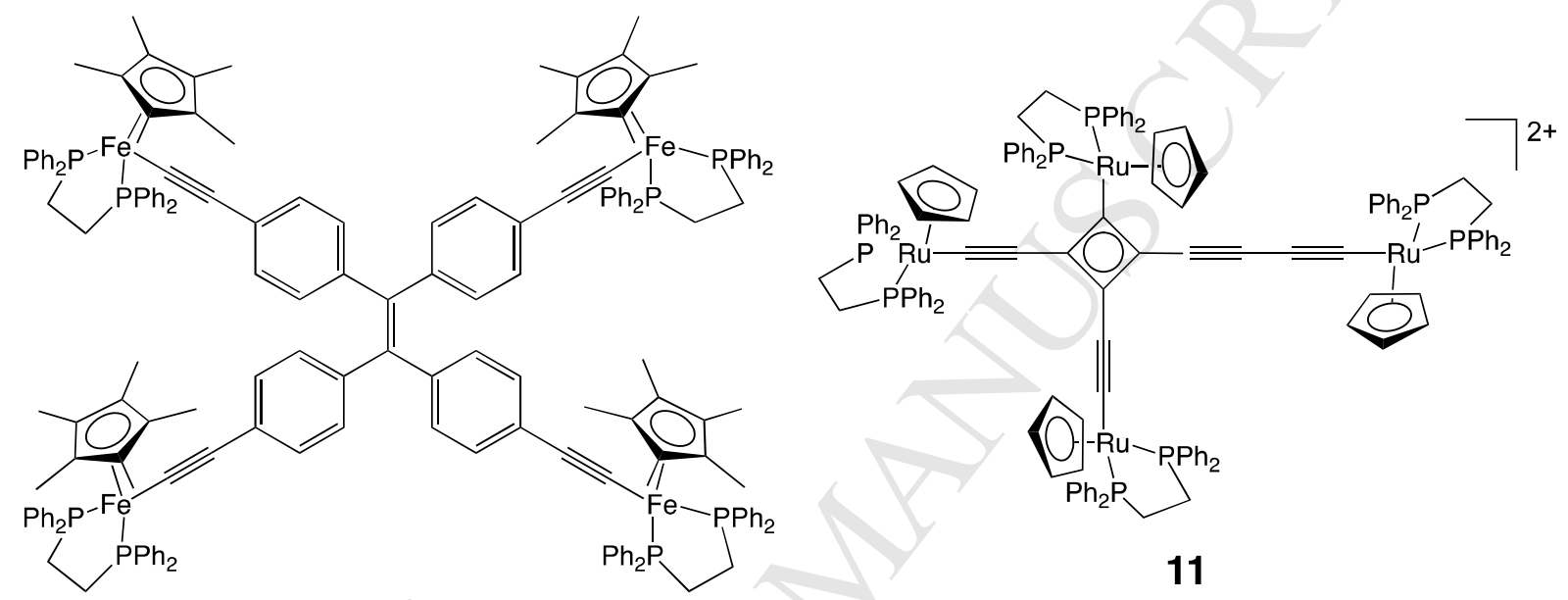

10

Scheme 4. "Square" complexes 10 and 11.

\section{Surface attachment of mixed-valence complexes}

For ultimate use in QCA devices, candidate molecules must be suitable for binding either chemically or physically to surfaces. For chemical attachment, the MV compounds need to be functionalized. Starting from the Class-II MV heterometallic trans- $\left.\left[\mathrm{RuCl}(\mathrm{dppm})_{2}(\mathrm{C} \equiv \mathrm{C}) \mathrm{Fc}\right)\right]^{+}$ species $(\mathrm{dppm}=$ methylbis(diphenylphosphane) [31], Fehlner and coworkers were able to prepare and characterize the "tailed" MV complex trans$\left.\left[\mathrm{Ru}(\mathrm{dppm})_{2}(\mathrm{C} \equiv \mathrm{C}) \mathrm{Fc}\right)\left(\mathrm{NCCH}_{2} \mathrm{CH}_{2} \mathrm{NH}_{2}\right)\right]^{+} \quad(\mathbf{1 2}$, Scheme 5) and to bind it to $\mathrm{Au}$ and $\mathrm{Si}$ substrates (covalently modified with $\mathrm{HS}\left(\mathrm{CH}_{2}\right)_{10} \mathrm{COOH}$ in the case of the former) [31-33]. A measurement of the capacitance between the two redox centers of this double-dot MV cation 
attached to a Si surface shows that upon the application of an external electric field a switchable bistable $\mathrm{Fe}(\mathrm{III})-\mathrm{Ru}(\mathrm{II})$ vs. $\mathrm{Fe}(\mathrm{II})-\mathrm{Ru}(\mathrm{III})$ charge configuration, an essential property necessary for a QCA cell [32]. Identically, the MV homobimetallic trans$\left[\left(\mathrm{H}_{2} \mathrm{NCH}_{2} \mathrm{CH}_{2} \mathrm{CN}\right)(\text { dppe })_{2} \mathrm{Ru}(\mathrm{C} \equiv \mathrm{C})_{6} \mathrm{Ru}(\text { dppe })_{2}\left(\mathrm{NCCH}_{2} \mathrm{CH}_{2} \mathrm{NH}_{2}\right)\right]^{2+} \quad(\mathbf{1 3}$ ', Scheme 5), a derivative of trans $-\left[\mathrm{Cl}(\mathrm{dppe})_{2} \mathrm{Ru}(\mathrm{C} \equiv \mathrm{C})_{6} \mathrm{Ru}(\mathrm{dppe})_{2} \mathrm{Cl}\right]$ (13, Scheme 5) functionalized for binding to a silicon substrate, exhibits two stable MV forms differing in the spatial location of one electron [34]. Comparison of the switching signal obtained from $\mathbf{1 2}$ and $\mathbf{1 3}$ indicates that the dipolar switching field increases by increasing the length of the conjugated carbon linker between the metal end groups. Additionally, the size of the counterion may affect the switching potential magnitudes.

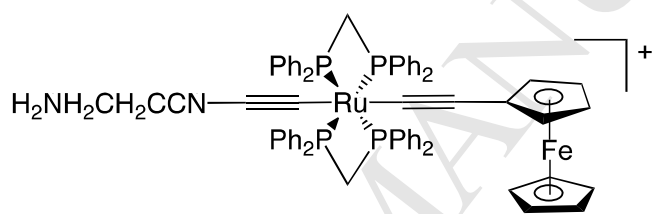

12

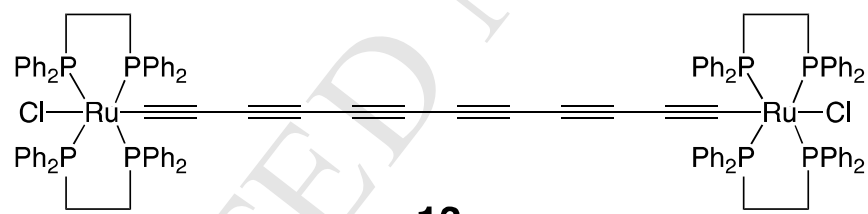

13

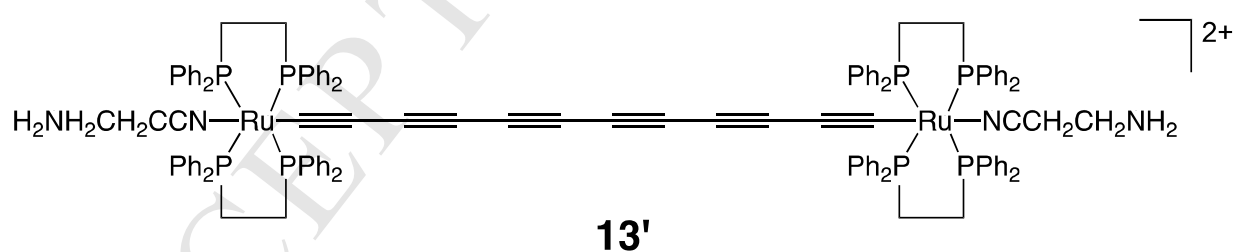

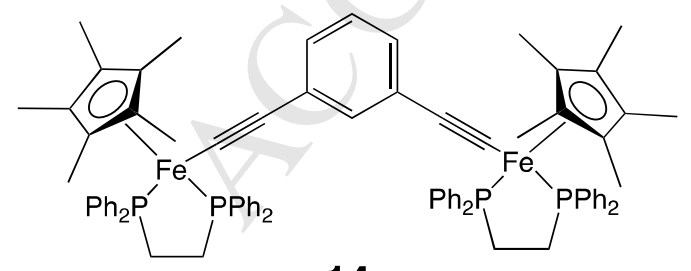

14

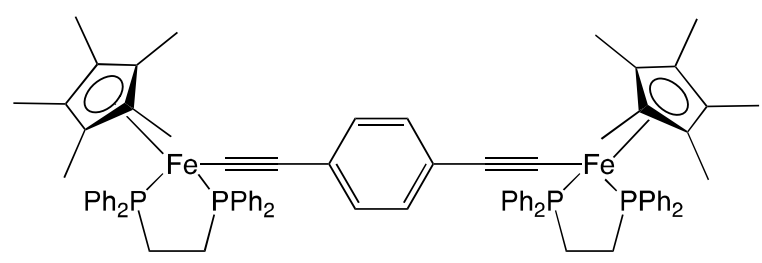

15

Scheme 5. Complexes 12-15.

Charge bistability has also been experimentally demonstrated for MV organometallic complexes physically deposited on Au surface [35-39]. Kandel et al. for instance, have shown 
via scanning tunneling microscopy (STM) that the mono-oxidation of the wire-like compound 13' on $\mathrm{Au}(111)$ surface at $77 \mathrm{~K}$ creates an unbalanced charge that localizes on one end group of the molecule reflecting a Class-II behavior [35,36]. They also used STM to image the dinuclear metal compounds $\left[\left\{\mathrm{Cp}^{*}(\mathrm{dppe}) \mathrm{Fe}(\mathrm{C} \equiv \mathrm{C}-)\right\}_{2}\left(1,3-\mathrm{C}_{6} \mathrm{H}_{4}\right)\right]^{+}$and $[\{\mathrm{Cp} *(\mathrm{dppe}) \mathrm{Fe}(\mathrm{CC}-$ )$\left.\}_{2}\left(1,4-\mathrm{C}_{6} \mathrm{H}_{4}\right)\right]^{+}(\mathbf{1 4}$ and $\mathbf{1 5}$, Scheme 5) prepared by Lapinte and collobarators [40] showing Class-II and Class-III species, respectively [37,38]. This indicates that the former could act as an excellent candidate for a molecular half-QCA cell.

\section{To new QCA candidates}

Our own interest in MV organometallic iron and/or ruthenium organometallic "wires" over the last years [30,40-43] led us to explore the possibility of exploiting their charge-transfer properties to create new QCA molecular components. Our choice fell on compounds inspired from Lapinte's iron wire-like MV complexes rather than Bruce's ruthenium analogues since it is known that the former ones "retain" better the charge on the metal centers than the latter ones [42-44]. Moreover, lengthening of the carbon chain might also facilitate metal charge localization, but it might also increase the distance between the metal sites and this must be detrimental for the efficiency of the QCA. A subtle compromise has to be found. With this in mind, double-dot and four-dot MV molecules such as $\left[\left\{\mathrm{Cp}^{*}(\mathrm{dppe}) \mathrm{Fe}(\mathrm{C} \equiv \mathrm{C}-)\right\}_{2}(1,2-\mathrm{C}=\mathrm{C})\right]^{+}$ (16), $\left[\left\{\mathrm{Cp}^{*}(\mathrm{dppe}) \mathrm{Fe}(\mathrm{C} \equiv \mathrm{C})\left(1,4-\mathrm{C}_{6} \mathrm{H}_{4}\right)(\mathrm{C} \equiv \mathrm{C}-)(1,2-\mathrm{C}=\mathrm{C})\right]^{+} \quad(\mathbf{1 7}), \quad\left[\right.\right.$ cyclo- $\left\{\mathrm{Cp}^{*}(\mathrm{dppe}) \mathrm{Fe}(\mathrm{C} \equiv \mathrm{C}-\right.$ )$\left.\}_{4} \mathrm{C}_{4}\left(\eta^{4}-\mathrm{ML}_{\mathrm{n}}\right)\right]^{2+}\left(\mathrm{ML}_{\mathrm{n}}=\mathrm{Fe}(\mathrm{CO})_{3}(\mathbf{1 8}), \mathrm{CoCp}(\mathbf{1 9})\right)$ and $[$ cyclo- $\{\mathrm{Cp} *(\mathrm{dppe}) \mathrm{Fe}(\mathrm{C} \equiv \mathrm{C})(1,4-$ $\left.\left.\left.\mathrm{C}_{6} \mathrm{H}_{4}\right)(\mathrm{C} \equiv \mathrm{C}-)\right\}_{4} \mathrm{C}_{4}\left(\eta^{4}-\mathrm{ML}_{\mathrm{n}}\right)\right]^{2+}\left(\mathrm{ML}_{\mathrm{n}}=\mathrm{Fe}(\mathrm{CO})_{3}(\mathbf{2 0})\right.$, CoCp (21)) were then constructed (Scheme 6) from the linkage of $\mathrm{Cp}^{*}($ dppe $) \mathrm{Fe}(\mathrm{C} \equiv \mathrm{C}-)$ or $\mathrm{Cp}^{*}(\mathrm{dppe}) \mathrm{Fe}(\mathrm{C} \equiv \mathrm{C})\left(1,4-\mathrm{C}_{6} \mathrm{H}_{4}\right)(\mathrm{C} \equiv \mathrm{C}-)$ moieties via ethene-like $C_{2}$ and cyclobutadiene-like $C_{4}$ spacers and theoretically studied via DFT calculations to analyze the effects of different bridging and ancillary ligands. In order to reduce computational effort, calculations were first carried out on model molecules (16-H-21- 
H) where dppe and $\mathrm{Cp}^{*}$ were replaced by $\mathrm{H}_{2} \mathrm{PCH}_{2} \mathrm{CH}_{2} \mathrm{PH}_{2}$ (dpe) and $\mathrm{Cp}$, respectively. We report here some preliminary results obtained for the former ones $\mathbf{1 6 - H}$ and $\mathbf{1 7 - H}$.

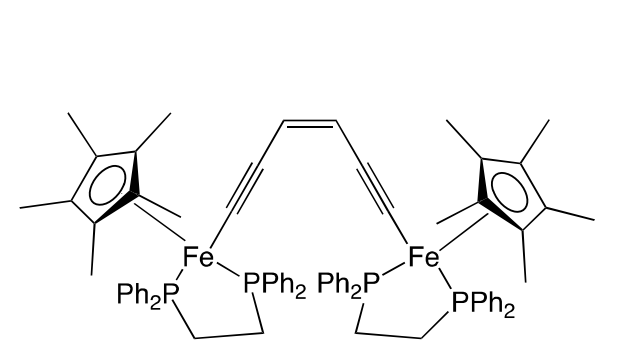

16

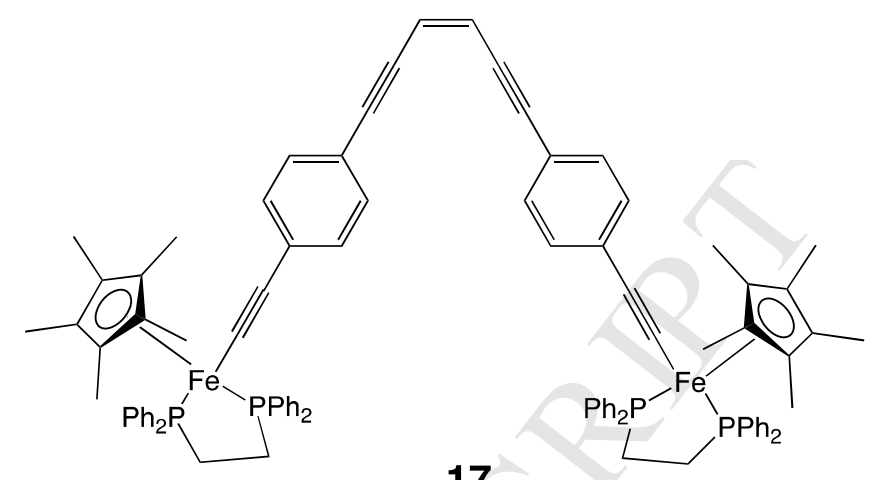

17

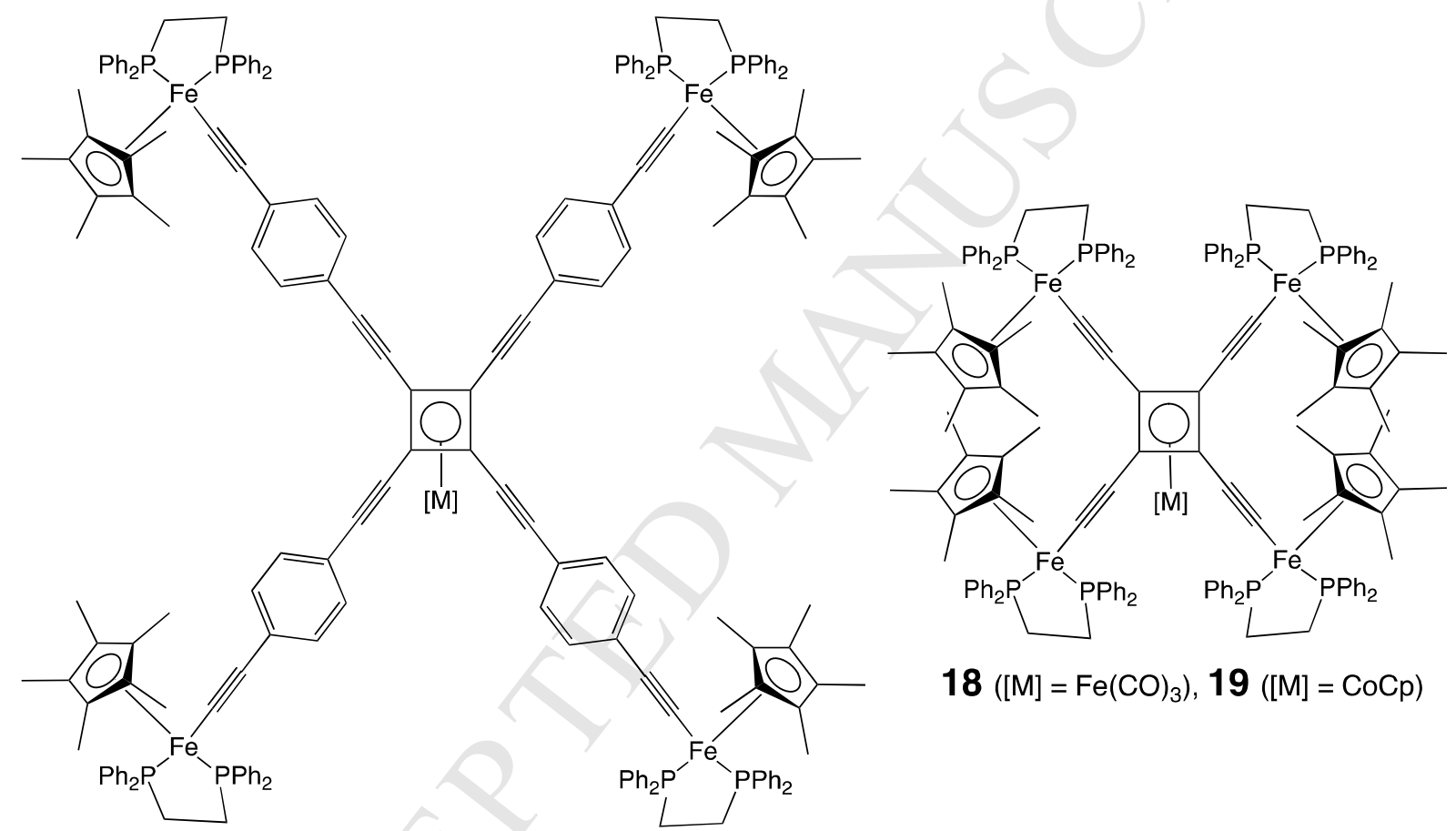

$20\left([\mathrm{M}]=\mathrm{Fe}(\mathrm{CO})_{3}\right), 21([\mathrm{M}]=\mathrm{CoCp})$

Scheme 6. Hypothetical QCA candidate complexes 16-21.

Neutral and MV cationic model species $\mathbf{1 6 - \mathbf { H } ^ { \mathbf { n } + }}$ and $\mathbf{1 7}-\mathbf{H}^{\mathbf{n +}}(n=0,1)$ were first optimized. Pertinent metrical parameters are given and compared in Table 1. As expected for this kind of molecules [40] upon oxidation the $\mathrm{Fe}-\mathrm{C}$ bonds contract substantially whereas the $\mathrm{C} \equiv \mathrm{C}$ bonds slightly lengthen. Interestingly, the $\mathrm{Fe}_{1}-\mathrm{C}_{1}$ and $\mathrm{Fe}_{2}-\mathrm{C}_{4}$ bonds notably differ in both cationic species $\mathbf{1 6 - \mathbf { H } ^ { + }}$ and $\mathbf{1 7 - \mathbf { H } ^ { + }}$ by more than $0.2 \AA$. This renders the molecules slightly asymmetric, 
indicating some localization character with formally Fe(II) and Fe(III) centers (Class-II MV compounds). This polarization character is reflected in the nodal properties of the highestoccupied and lowest unoccupied spin-orbitals (see Figures 1S and 2S in Supplementary Information), the spin densities and electrostatic potentials (ESP) (Figure 2). It is noteworthy that the charge dissymmetry is overall weaker in $\mathbf{1 6}-\mathbf{H}^{+}$than in $\mathbf{1 7 - \mathbf { H } ^ { + }}$.
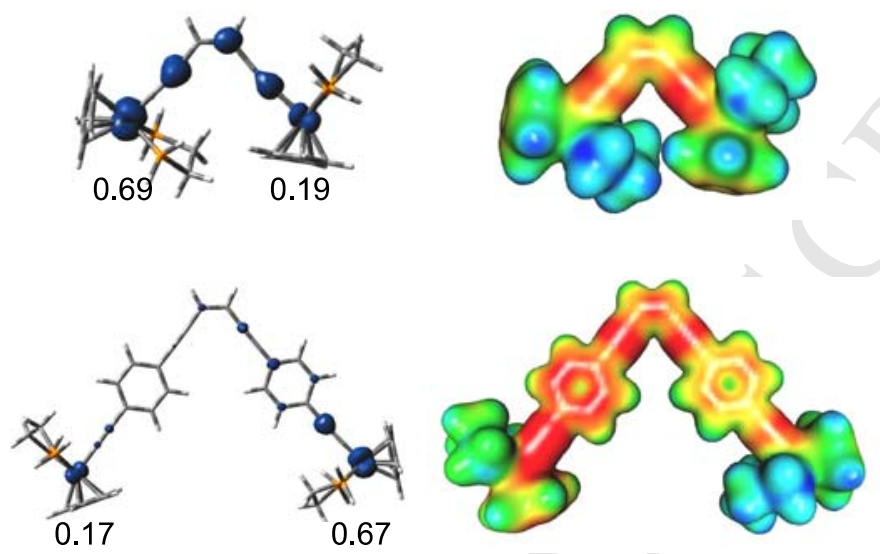

Figure 2. Spin density (left) and electrostatic potential (ESP) mapping (right) of $\mathbf{1 6 - \mathbf { H } ^ { + }}$ (top) and $\mathbf{1 7}-\mathbf{H}^{+}$(bottom). Numerical parameters indicate Mulliken atomic spin density. Contour values are $\pm 0.004\left(\mathrm{e}^{\mathrm{bohr}}{ }^{-3}\right)$ and $\pm 0.01\left(\mathrm{e} \mathrm{bohr}^{-3}\right)$ for the spin density and the ESP, respectively.

\section{Table 1}

Computed bond lengths $(\AA)$ for neutral and MV cationic model species 16-H and 17-H (see below for atom numbering).

\begin{tabular}{ccccc}
\hline bond & $\mathbf{1 6 - H}$ & $\mathbf{1 6}^{+} \mathbf{H}^{+}$ & $\mathbf{1 7 - H}$ & $\mathbf{1 7 - H}^{+}$ \\
\hline $\mathrm{Fe}(1)-\mathrm{C}(1)$ & 1.898 & 1.825 & 1.889 & 1.861 \\
$\mathrm{Fe}(2)-\mathrm{C}(4)$ & 1.899 & 1.850 & 1.889 & 1.842 \\
$\mathrm{Fe}(1)-\mathrm{P}(1)$ & 2.249 & 2.273 & 2.247 & 2.257 \\
$\mathrm{Fe}(1)-\mathrm{P}(2)$ & 2.266 & 2.266 & 2.248 & 2.254 \\
$\mathrm{Fe}(2)-\mathrm{P}(3)$ & 2.250 & 2.262 & 2.247 & 2.274 \\
$\mathrm{Fe}(2)-\mathrm{P}(4)$ & 2.266 & 2.258 & 2.245 & 2.267 \\
$\mathrm{C}(1)-\mathrm{C}(2)$ & 1.243 & 1.253 & 1.241 & 1.246 \\
$\mathrm{C}(3)-\mathrm{C}(4)$ & 1.243 & 1.253 & 1.241 & 1.247 \\
$\mathrm{Fe}(1) \ldots \mathrm{Fe}(2)$ & 6.252 & 7.464 & 14.858 & 15.765 \\
\hline
\end{tabular}



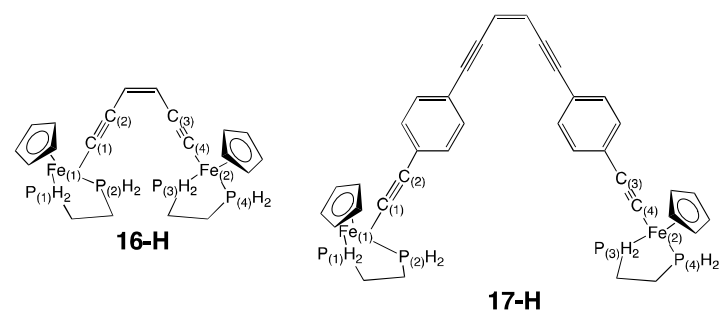

For QCA operation the molecular charge distribution of one molecule must respond in a nonlinear fashion to the Coulombic perturbation produced by the neighboring molecule switching from one state ("1") to another ("0"). The Coulomb field produced by the neighboring molecules can be considered the input to the molecular device, whereas the resulting charge configuration can be considered as its output $[4,17,18]$. The chargepolarization response of MV models $\mathbf{1 6}-\mathbf{H}^{+}$than in $\mathbf{1 7 - \mathbf { H } ^ { + }}$ with respect to a neighboring molecule (driver) was calculated. The biasing charge (driver) was modeled by a $\mathrm{Li}^{+}$cation located parallel to the iron-iron axis, as shown in Figure 3 either on the side of $\mathrm{Fe}(\mathrm{II})$ center or on the side of $\mathrm{Fe}(\mathrm{III})$ center at a distance roughly equal to the intramolecular $\mathrm{Fe}{ }^{\cdots \cdots} \mathrm{Fe}$ distance to mimic the polarization of a half-QCA cell induced by the polarization of the neighboring half-QCA cell, as would be the case in a half QCA. It appears that when the driver is next to the 18-electron $\mathrm{Fe}(\mathrm{II})$ center $\left(\mathrm{Fe}_{2}\right.$ in $\mathbf{1 6}-\mathbf{H}^{+}$and $\mathrm{Fe}_{1}$ in $\mathbf{1 7 - \mathbf { H } ^ { + }}$ ), electron localization is reinforced since the Fe(II) spin density decreases from 0.19 and 0.17 to 0.09 and 0.04 whereas the $\mathrm{Fe}(\mathrm{III})$ spin density increases from 0.69 and 0.67 to 0.88 and 0.89 for $\mathbf{1 6 - \mathbf { H } ^ { + }}$ than in $\mathbf{1 7 -}$ $\mathbf{H}^{+}$, respectively. On the other hand, if $\mathrm{Li}^{+}$is placed next to the 17 -electron $\mathrm{Fe}(\mathrm{III})$ center, the spin densities of the two iron centers are exchanged moving from 0.69 and 0.67 to 0.19 and 0.13 for the initially $\mathrm{Fe}(\mathrm{II})$ center and from 0.19 and 0.17 to 0.66 and 0.71 for the initially $\mathrm{Fe}(\mathrm{III})$ center. In other words, $\mathrm{Fe}(\mathrm{II})$ becomes now Fe(III) and vice-versa. This is also nicely illustrated looking at the ESP maps shown in Figure 3. $\mathrm{As}^{+}{ }^{+}$has been placed far away (ca. 7.5 and $15 \AA$ for $\mathbf{1 6}-\mathbf{H}^{+}$and $\mathbf{1 7}-\mathbf{H}^{+}$, respectively), no charge transfer or strong interaction occurs between the cationic molecule and the driver. This indicates clearly that such a charge 
switch is only due to long-range electrostatic interactions, just like how QCA cells should interact to each other.

(a)
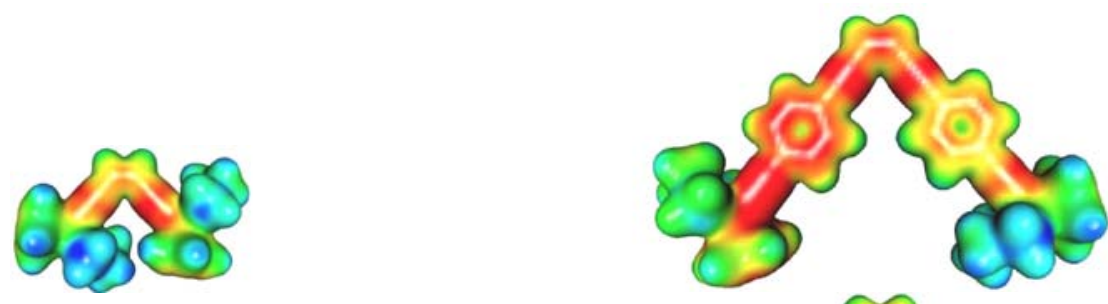

(b)
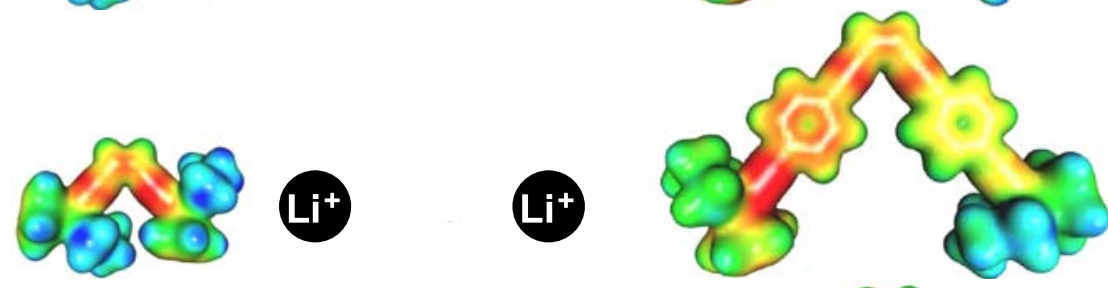

(c)
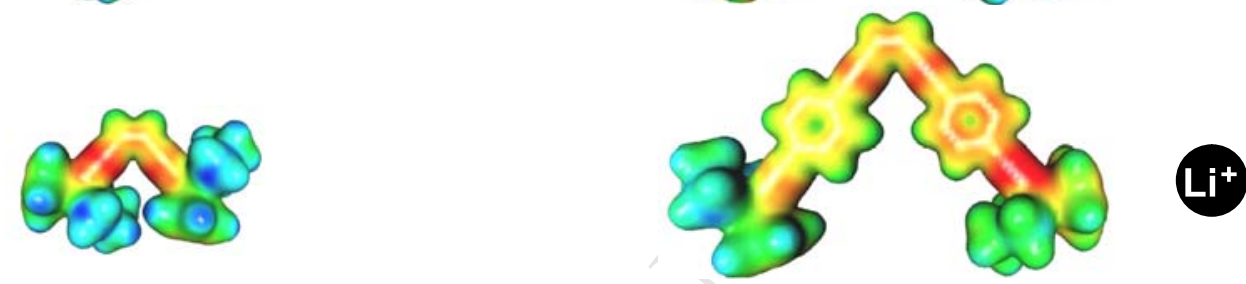

Figure 3. (a) ESP of $\mathbf{1 6}-\mathbf{H}^{+}$(left) and $\mathbf{1 7 - \mathbf { H } ^ { + }}$ right); (b) ESP of $\mathbf{1 6 - \mathbf { H } ^ { + }}$ (left) and $\mathbf{1 7 - \mathbf { H } ^ { + }}$ (right) with the $\mathrm{Li}^{+}$driver near the initially $\mathrm{Fe}(\mathrm{II})$ center. (c) ESP of $\mathbf{1 6}-\mathbf{H}^{+}$(left) and $\mathbf{1 7 - \mathbf { H } ^ { + }}$ (left) with the $\mathrm{Li}^{+}$driver near the initially $\mathrm{Fe}(\mathrm{III})$ center. Contour values are \pm 0.01 (e bohr ${ }^{-3}$ )

The $\mathrm{Li}^{+}$cation driver was also located parallel to the iron-iron axis, but above and shuttled along this axis, to mimic the polarization that would occur within a four-dot QCA cell. Figure 4 shows the spin density of the iron $\mathrm{Fe}(\mathrm{II})$ and $\mathrm{Fe}(\mathrm{III})$ centers with respect to the position of the $\mathrm{Li}^{+}$driver for $\mathbf{1 7}-\mathrm{H}^{+}$. Interestingly, the ideal behavior which would be two curves with two plateaus that switch sharply between the two electronic configurations, is almost reached. A rather sharp switch of the two curves occurs at a position about $12 \AA$ away from the starting position above one of the iron centers (see Figure 4). Although our calculations are not that accurate - the geometry of $\mathbf{1 7}-\mathbf{H}^{+}$was not optimized during the $\mathrm{Li}^{+}$shuttling - they indicate that nonlinear polarization can be achieved when a biasing charge is added to this system. 


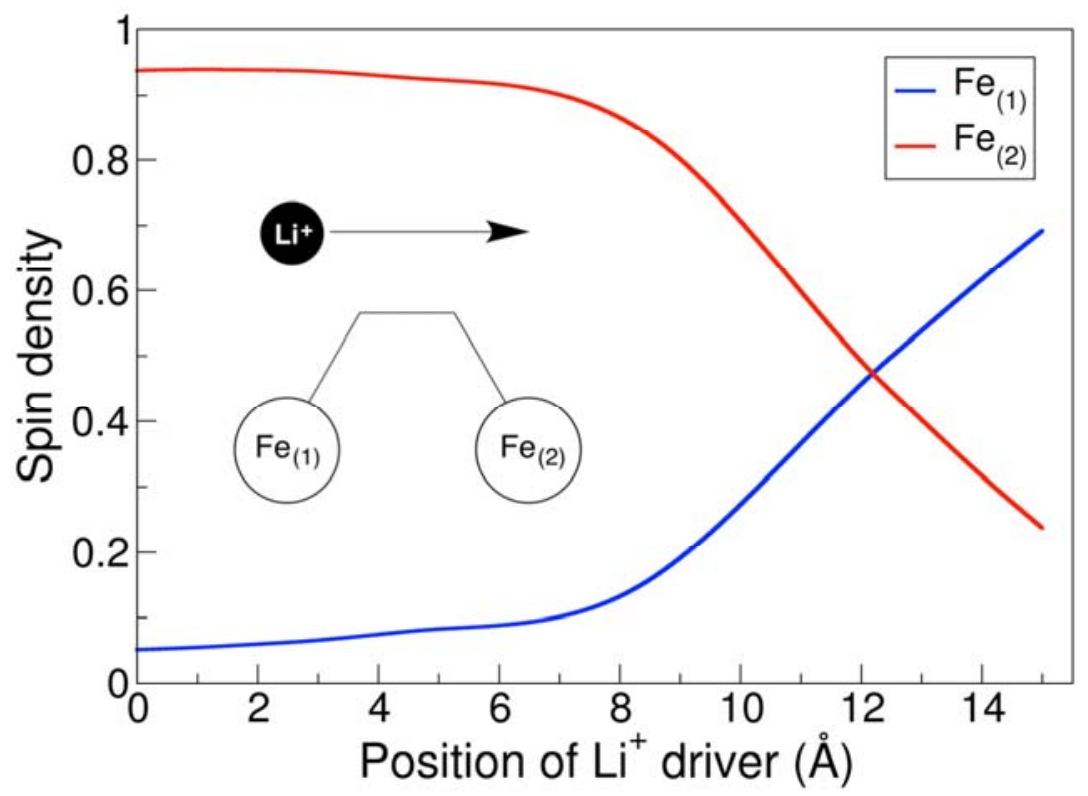

Figure 4. Change of the spin density of $\mathrm{Fe}(1)$ (initially $\mathrm{Fe}(\mathrm{II})$, blue curve) and $\mathrm{Fe}(2)$ (initially $\mathrm{Fe}(\mathrm{III})$, red curve) as function of the position of the $\mathrm{Li}^{+}$driver shuttled along the $\mathrm{Fe}(1)^{\cdots} \mathrm{Fe}(2)$ axis for $\mathbf{1 7}-\mathbf{H}^{+} . \mathbf{L i}+$ was initially placed above $\mathrm{Fe}(1)$ at ca. $15 \AA$.

\section{Conclusion}

The couple of MV model organometallic iron compounds which have been examined here via DFT calculations, possesses properties that may permit their use as molecular QCA building blocks. Indeed, results suggest that i) a valence trapping (Class-II) is observed and that ii) a significant polarization occurs when a biasing charge is added to the systems, satisfying the key requirement for QCA operation. Encouraged by these results, future theoretical studies will be carried out to identify "real" complexes which may develop this bistable and switchable charge configuration property before they are synthesized. Particular attention will be given to the nature and the length of the carbon linker which has important consequences for the use of such molecules for QCA. 


\section{Acknowledgment}

The authors thank GENCI (Grand Equipement National de Calcul Intensif ) for HPC resources (grant c2015087367), and Prof. C. Lapinte (Rennes) for helpful discussions.

\section{Appendix A. Computational Details}

Calculations were performed at the DFT level with the Gaussian 09 package [45]. The geometry optimizations were performed with a $6-31+\mathrm{G}^{*}$ basis set for light atoms $(\mathrm{H}, \mathrm{C}, \mathrm{N}, \mathrm{P}$, Li) and a Def2-SVP basis set for Fe [46]. The PBE0 functional [47] was used. Driver's effect methodology was inspired from Braun-Sand, Wiest, and Tokunaga previous works [23-26]. Electrostatic Potential mapping on Electronic Density was performed using the Gabedit software [48].

\section{Appendix B. Supplementary material}

A MOL file giving Cartesian coordinates for all calculated geometries. Spin-orbital diagrams of $\mathbf{1 6}-\mathbf{H}^{+}$and $\mathbf{1 7 - \mathbf { H } ^ { + }}$ (Figures S1 and S2).

\section{References}

[1] G.E. Moore, Electronics 38 (1965) 114.

[2] S. Marqués-González, P.J. Low, Aust. J. Chem. 69 (2016) 244.

[3] C.S. Lent, P.D. Tougaw, W. Porod, G.H. Bernstein, Nanotechnology 4 (1993) 49.

[4] Y. Lu, C.S. Lent, Nanotechnology 19 (2008) 155703.

[5] C.S. Lent, B. Isaksen, M. Lieberman, J. Am. Chem. Soc. 125 (2003) 1056.

[6] A.O. Orlov, I. Amlani, G.H. Bernstein, C.S. Lent, G.L. Snider, Science 277 (1997) 928.

[7] I. Amlani, A.O. Orlov, G. Toth, G.H. Bernstein, C.S. Lent, G.L. Snider, Science 284 (1999) 289. 
[8] C.S. Lent, Science 288 (2000) 1597.

[9] A.O. Orlov, I. Amlani, G. Toth, C.S. Lent, G.H. Bernstein, G.L. Snider, Appl. Phys. Lett. $74(1999) 2875$.

[10] J. Glanz, J. Science 269 (1995) 1363.

[11] Y. Wang, M. Lieberman, IEEE Trans. Nanotechnol. 3 (2004) 368.

[12] M.B. Robin, P. Day, Adv. Inorg. Chem. Radiochem. 10 (1967) 247-422.

[13] P. Day, N.S. Hush, R. J.H. Clark, Phil. Trans. R. Soc. A 366 (2008) 5.

[14] D.E. Richardson and H. Taube, Coord. Chem. Rev. 60 (1984) 107.

[15] C. Creutz, H. Taube, J. Am. Chem. Soc. 91 (1969) 3988.

[16] V.C. Lau, L.A. Berben, J.R. Long, J. Am. Chem. Soc. 124 (2003) 9042.

[17] S.B. Braun-Sand, O. Wiest, J. Phys. Chem. A 107 (2003) 285.

[18] S.B. Braun-Sand, O. Wiest, J. Phys. Chem. B 107 (2003) 9624.

[19] K. Tokunaga, Phys. Chem. Chem. Phys. 11 (2009) 1474.

[20] K. Tokunaga, Materials 3 (2010) 4277.

[21] J. Jiao, G.J. Long, F. Grandjean, A.M. Beatty, T.P. Fehlner, J. Am. Chem. Soc. 125 (2003) 7522.

[22] J. Jiao, G.J. Long, L. Rebbouh, F. Grandjean, A.M. Beatty, T.P. Fehlner, J. Am. Chem. Soc. 127 (2005) 17819.

[23] Y. Lu, C.S. Lent, J. Comput. Electron. 4 (2005) 115-118.

[24] K.B. Vincent, J.B.G. Gluyas, S. Gückel, Q. Zeng, F. Hartl, M. Kaupp, P.J. Low, J. Organomet. Chem. 821 (2016) 40.

[25] V.N. Nemykin, G.T. Rohde, C.D. Barett, R.G. Hadt, C. Bizzarri, P. Galloni, B. Floris, I. Nowik, R.H. Herber, A.G. Marrani, R. Zanoni, N.M. Loim, J. Am. Chem. Soc. 131 (2009) 14969. 
[26] K. Tahara, N. Terashita, T. Akita, S. Katao, J. Kikuchi, K. Tokunaga, Organometallics $34(2015) 299$.

[27] B. Schneider, S. Demeshko, S. Neudeck, S. Dechert, F. Meyer, Inorg. Chem. 52 (2013) 13230.

[28] Y. Zhao, D. Guo, Y. Liu, C. He, C. Duan, Chem. Commun. (2008) 5725.

[29] Y. Tanaka, T. Ozawa, A. Inagaki, M. Akita, Dalton Trans. (2007) 928.

[30] A. Burgun, F. Gendron, P.A. Schauer, B.W. Skelton, P.J. Low, K. Costuas, J.-F. Halet, M.I. Bruce, C. Lapinte, Organometallics 32, (2013) 5015.

[31] Z. Li, A.M. Beatty, T.P. Fehlner, Inorg. Chem. 42 (2003) 5707.

[32] H. Qi, S. Sharma, Z. Li, G.L. Snider, A.O. Orlov, C.S. Lent, T.P. Fehlner, J. Am. Chem. Soc. 125 (2003) 15250.

[33] Z. Li and T.P. Fehner, Inorg. Chem. 42 (2003) 5715.

[34] H. Qi, A. Gupta, B.C. Noll, G.L. Snider, Y. Lu, C. Lent, T.P. Fehlner, J. Am. Chem. Soc. $127(2005) 15218$.

[35] Z Wei, S. Guo, S.A. Kandel, J. Phys. Chem. B 110 (2006) 21846.

[36] S. Guo, S.A. Kandel, J. Phys. Chem. Lett. 1 (2010) 420.

[37] Y. Lu, R. Quardokus, C.S. Lent, F. Justaud, C. Lapinte, S.A. Kandel, J. Am. Chem. Soc. 132, (2010) 13519.

[38] R.C. Quardokus, Y. Lu, N.A. Wasio, C.S. Lent F. Justaud, C. Lapinte, S.A. Kandel, J. Am. Chem. Soc. 134 (2012) 1710.

[39] N.A. Wasio, R.C. Quardokus, R.P. Forrest, S.A. Corcelli, Y. Lu, C.S. Lent, F. Justaud, C. Lapinte, S.A. Kandel, J. Phys. Chem. C 116 (2012) 25486.

[40] J.-F. Halet, C. Lapinte, Coord. Chem. Rev. 257 (2013) 1584.

[41] M.I. Bruce, P.J. Low, K. Costuas, J.-F. Halet, S.P. Best, G.A. Heath, J. Am. Chem. Soc. $122(2000) 1949$. 
[42] F. Gendron, A. Burgun, B.W. Skelton, A.H. White, T. Roisnel, M.I. Bruce, J.-F. Halet,

C. Lapinte, K. Costuas, Organometallics 31 (2012) 6796.

[43] A. Burgen, F. Gendron, C.J. Sumby, T. Roisnel, O. Cador, K. Costuas, J.-F. Halet, M. I. Bruce, C. Lapinte, Organometallics 33 (2014) 2613.

[44] P.J. Low, Coord. Chem. Rev. 257 (2013) 1507.

[45] M.J. Frisch, G.W. Trucks, H.B. Schlegel, G.E. Scuseria, M.A. Robb, J.R. Cheeseman, G.

Scalmani, V. Barone, B. Mennucci, G.A. Petersson, H. Nakatsuji, M. Caricato, X. Li, H.P. Hratchian, A.F. Izmaylov, J. Bloino, G. Zheng, J.L. Sonnenberg, M. Hada, M. Ehara, K. Toyota, R. Fukuda, J. Hasegawa, M. Ishida, T. Nakajima, Y. Honda, O. Kitao, H. Nakai, T. Vreven, J.A. Montgomery Jr., J.E. Peralta, F. Ogliaro, M. Bearpark, J.J. Heyd, E. Brothers, K.N. Kudin, V.N. Staroverov, R. Kobayashi, J. Normand, K. Raghavachari, A. Rendell, J.C. Burant, S.S. Iyengar, J. Tomasi, M. Cossi, N. Rega, J.M. Millam, M. Klene, J.E. Knox, J.B. Cross, V. Bakken, C. Adamo, J. $\square$ Jaramillo, R. Gomperts, R.E. Stratmann, O. Yazyev, A.J. Austin, R. Cammi, C. Pomelli, J.W. Ochterski, R.L. Martin, K. Morokuma, V.G. Zakrzewski, G.A. Voth, P. Salvador, J.J. Dannenberg, S. Dapprich, A.D. Daniels, Ö. Farkas, J.B. Foresman, J.V. Ortiz, J. Cioslowski, D.J. Fox, Gaussian 09, Revision E.01, 2009, Gaussian, Inc., Wallingford CT.

[46] F. Weigend, R. Ahlrichs, Phys. Chem. Chem. Phys. 7 (2005), 3297.

[47] C. Adamo,V. Barone, J. Chem. Phys. 110 (1999) 6158.

[48] A.-R. Allouche, J. Comput. Chem. 32 (2011) 174. 


\section{Theoretical studies of mixed-valence organometallic species for potential utilization as quantum cellular automata}

Thomas Groizard, Samia Kahlal, Jean-François Halet*

Institut des Sciences Chimiques de Rennes, UMR 6226 CNRS-Université de Rennes 1, Avenue du Général Leclerc, F-35042 Rennes Cédex, France

\section{Highlights}

- Modeling of mixed-valence organometallic half-QCA candidates.

- Localization vs. delocalization of the charge.

- Exploration of cell-to-cell information transfer via $\mathrm{Li}^{+}$driver. 